\title{
SPECTRUM OF MALIGNANT SKIN LESION IN PATIENTS ATTENDING NEPALGUNJ MEDICAL COLLEGE AND TEACHING HOSPITAL
}

\author{
Rana $R^{1^{*}}$, Ghimire $G P^{2}$, Gupta $S^{3}$, Singh $M,{ }^{1}$ Jha $K K,{ }^{1}$ Kafle $S U^{4}$
}

\section{Affiliation}

1. Lecturer, Department of Pathology, Birat Medical College and Teaching Hospital, Tankisinuwari, Morang, Nepal

2. Assistant Professor, Department of Pathology, Nepalgunj Medical College and Teaching Hospital, Nepal

3. Lecturer, Department of Pathology, Nepalgunj Medical College and Teaching Hospital, Nepal

4. Associate Professor, Department of Pathology, Birat Medical College and Teaching Hospital, Nepal

\section{ARTICLE INFO}

\section{Article History}

Received : 10 March, 2017

Accepted : 30 June, 2017

Published : 30 August, 2017

(C) Authors retain copyright and grant the journal right of first publication with the work simultaneously licensed under Creative Commons Attribution License CC - BY 4.0 that allows others to share the work with an acknowledgment of the work's authorship and initial publication in this journal.

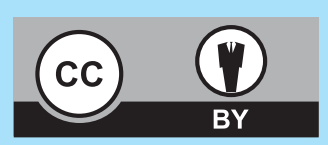

\section{ORA 23}

\author{
* Corresponding Author \\ Dr Reena Rana \\ Lecturer \\ Department of Pathology \\ Birat Medical College \& Teaching Hospital \\ Tankisinuwari, Morang, Nepal \\ Email: reenarana@hotmail.com
}

\section{Citation}

Rana R, Ghimire G P, Gupta S, Singh M, Jha KK, Kafle SU. Spectrum of Malignant Skin Lesion in Patients Attending Nepalgunj Medical College and Teaching Hospital. BJHS 2017;2 (2)3 : 156-161.

\begin{abstract}
Introduction

Clinical diagnosis of dermatological manifestation of neoplastic skin lesion can pose a diagnostic difficulty at times. Histopathological diagnosis is mandatory for accurate characterization of disease entity for proper and timely management of cases.
\end{abstract}

\section{Objective}

The aim of this study was to analyze malignant tumor of skin with respect to age, sex, clinical features and histopathological features and to evaluate the accuracy of clinical diagnosis with histopathological correlation.

\section{Methodology}

This is hospital based cross-sectional study conducted at Nepalgunj Medical College and Teaching Hospital, Kohalpur from February 2010 to January 2011. A total of 70 histopathological specimens of skin biopsies were studied and correlated with the clinical diagnosis. The data was entered into Microsoft office excel and analyzed using statistical package for social sciences (SPSS 17.0).

\section{Results}

Malignant tumor of skin constituted $21.4 \%$ of total cases. In malignant tumor, most common sites were head and neck regions followed by lower limb with keratinocytic tumors being in the majority. Most of the specimens (65.7\%) were obtained as excisional biopsies. Seven cases diagnosed as benign lesions clinically, turned out to be malignant on histopathological examination. Out of 13 cases in which clinical diagnosis was of malignancy, only 8 turned out to be malignant, thus for malignant lesions, the clinical diagnosis had a sensitivity of $53.3 \%$, specificity of $90.9 \%$ and a positive predictive value of $61.5 \%$.

\section{Conclusions}

Squamous cell carcinoma was the most common malignant tumor in this study and histopathological correlation significantly modifies the overall management in dermatological disorders where clinical diagnoses are equivocal.

\section{KEY WORDS}

Histopathology, malignant lesion, skin 


\section{INTRODUCTION}

The skin is affected by both internal and external conditions and other factors as it is exposed to a range of environmental hazards making it vulnerable to all manner of threats. Various lesions affecting the skin range from nonspecific inflammatory dermatoses, infective disease and neoplasms. This study was conducted in mid-western region of Nepal, which is a very hot and humid tropical region. Skin diseases are the common problems in such region. Among skin diseases, skin cancer if diagnosed in later stages, causes significant morbidity and mortality. Clinical diagnosis of dermatological manifestation of neoplastic skin lesion can pose diagnostic difficulty at times. The clinician in many cases suggest differential diagnosis which forms the basis for the pathologist to evaluate the particular skin biopsy. ${ }^{1}$ Histopathological diagnosis is mandatory for accurate characterization of disease entity for proper and timely management of cases. The aim of this study was to analyze malignant tumor of skin with respect to age, sex, clinical features and histopathological features and to evaluate the accuracy of clinical diagnosis with histopathological correlation.

\section{METHODOLOGY}

This is hospital based cross- sectional study conducted at Nepalgunj Medical College Teaching Hospital, Kohalpur from February 2010 to January 2011. A total of 70 histopathological specimens of skin biopsies were studied and correlated with the clinical diagnosis. The study was conducted after obtaining approval from Nepalgunj Medical College and Teaching Hospital. The personal details of the patient, clinical findings, laboratory reference number, gross and microscopic descriptions and final histopathological diagnosis were noted.Hematoxyline and Eosin stain (H\&E) was done routinely for histopathological examination. The skin tumors were classified according to World Health Organization classification of skin-2006. ${ }^{2}$

Inclusion criteria: Skin biopsies sent to the pathology department.

Exclusion criteria: Inadequateskin biopsies without clinical details.

The data was entered into Microsoft office excel and analyzed using statistical package for social sciences (SPSS 17.0).

\section{RESULT}

Out of 70 cases only 15 cases were malignant skin tumors comprising 6 cases $(40 \%)$ of SCC, followed by 4 cases of Malignant Melanoma (26.6\%) and three cases of BCC (20\%). One case each of Dermatofibrosarcoma protuberance (6.6\%) and Mucinous Eccrine Carcinoma (6.6\%). Benign tumor of the skin were more common than malignant tumor in this study period. The histological categorization according to the frequency of the cases are given in table 1 and 2 .
Table.1: Distribution of benign tumor $(n=22)$

\begin{tabular}{|l|c|}
\hline \multicolumn{1}{|c|}{ Benign Tumors } & Number of Cases \\
\hline Palimatixoma & 2 \\
\hline Eccrine cylindroma & 1 \\
\hline Keratinous cyst of pilar type & 2 \\
\hline Keratinous cyst of epidermal type & 2 \\
\hline Dermoid cyst & 2 \\
\hline Dermatofibroma & 3 \\
\hline Angiomyofibroblastoma & 1 \\
\hline Plexiform neurofibroma & 1 \\
\hline Capillary hemangioma & 3 \\
\hline Pyogenic granuloma & 4 \\
\hline Intradermal nevus & 1 \\
\hline
\end{tabular}

\section{Table 2: Distribution of malignant tumor $(n=15)$}

\begin{tabular}{|l|c|}
\hline Malignant Tumors & $\begin{array}{c}\text { Number of } \\
\text { Cases }\end{array}$ \\
\hline $\begin{array}{l}\text { Keratinocytic malignant lesions } \\
\text { Squamous cell carcinoma (SCC) } \\
\text { Basal cell carcinoma (BCC) }=3\end{array}$ & 9 \\
\hline Melanoma (MM) & 4 \\
\hline Dermatofibrosarcoma protuberans (DFSP) & 1 \\
\hline Mucinous eccrine carcinoma & 1 \\
\hline
\end{tabular}

In this study the malignant lesion were common in head/ neck region and then in lower limbs.

All the malignant lesions presented clinically as localized lesions and maximum of it were ulcerated followed by nodular lesion. Malignant lesions were more common in the 51 to 60 years age group followed by age group of 21- 30 years as shown in table 3. Maximum number of specimens (65.7\%) were obtained as excisional biopsies.

In our study, among the six cases of squamous cell carcinoma, five were well differentiated microscopically and one was of verrucous type (an extremely well-differentiated rare variant of SCC) in a 65 year old female which was present for 6 months on the right foot. The case had clinical diagnosis of pyogenic granuloma which turn out to be malignant in histopathological examination. The microphotograph of the lesion is shown in figure1. 
Table 3 : Histopathological groups of disease according to age distribution

\begin{tabular}{|c|c|c|c|c|c|c|c|c|}
\hline \multirow{2}{*}{$\begin{array}{l}\text { Age } \\
\text { group } \\
\text { (years) }\end{array}$} & \multirow{2}{*}{$\begin{array}{c}\text { Inflammatory } \\
\text { dermatoses } \\
\text { of known } \\
\text { etiology }\end{array}$} & \multirow{2}{*}{$\begin{array}{c}\text { Other } \\
\text { dermatoses }\end{array}$} & \multirow{2}{*}{$\begin{array}{l}\text { Malignant } \\
\text { tumor }\end{array}$} & \multicolumn{4}{|c|}{ Benign tumor } & \multirow[b]{2}{*}{ Total } \\
\hline & & & & Adnexal & Dermal & Vascular & Nevus & \\
\hline $1-10$ & 2 & 1 & - & 1 & 1 & - & - & 5 \\
\hline $11-20$ & - & 1 & 1 & 4 & 1 & 2 & 1 & 10 \\
\hline $21-30$ & 7 & 7 & 3 & 1 & 1 & 3 & - & 22 \\
\hline $31-40$ & 4 & 2 & 1 & - & - & - & - & 7 \\
\hline $41-50$ & 1 & 3 & 2 & 1 & 1 & - & - & 8 \\
\hline $51-60$ & 1 & - & 4 & - & - & 1 & - & 6 \\
\hline $61-70$ & 2 & 1 & 2 & 1 & - & - & - & 6 \\
\hline $71-80$ & - & 1 & 1 & 1 & 1 & 1 & - & 5 \\
\hline $81-90$ & - & - & 1 & - & - & - & - & 1 \\
\hline TOTAL & 17 & 16 & 15 & 9 & 5 & 7 & 1 & 70 \\
\hline
\end{tabular}

Figure 1: Verrucous carcinoma: endophytic, pushing growth pattern of well differentiated squamous cells. Minimal atypia and no foci of the usual squamous cell carcinoma (H \& E × 10).

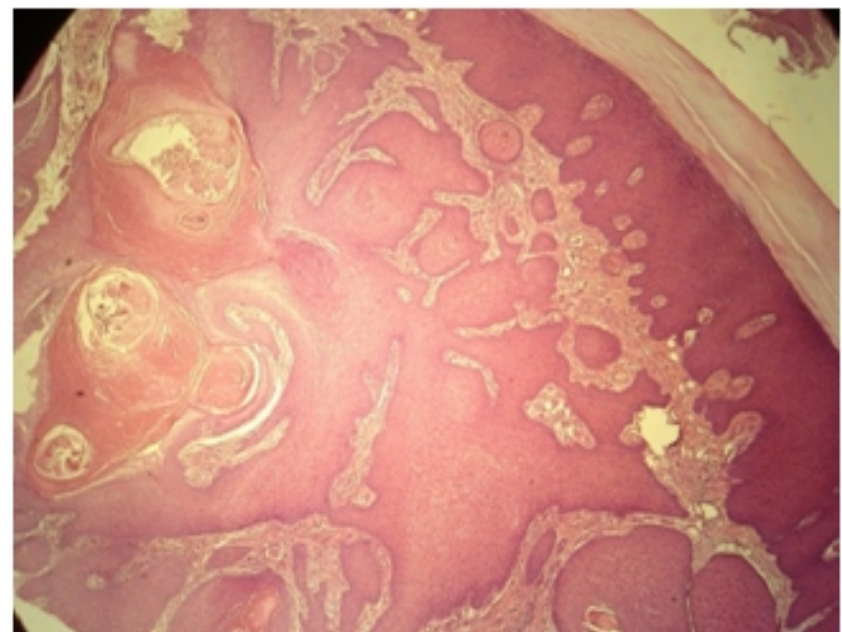

Photograph showing clinical presentation of one of the case of SCC with its photomicrograph is shown in Figure 2a, $2 b$.

Figure 2a: Squamous cell carcinoma, developing in the scar tissue of the right knee in a 26 year old male.

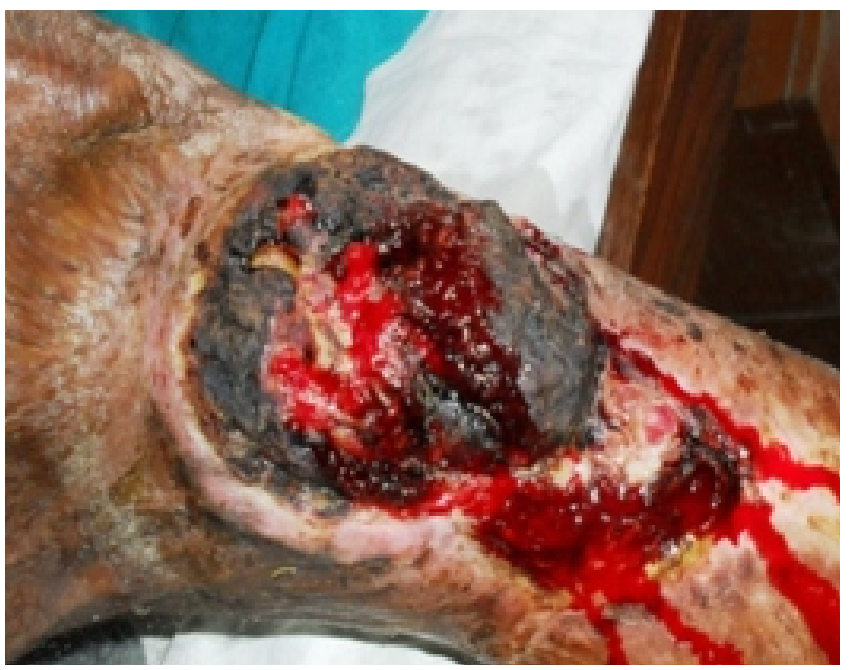

Figure $2 \mathrm{~b}$ : Photomicrograph of the same, showing invasive well differentiated SCC, hyperkeratosis, acanthosis, and tumor nests with keratin pearls (H\&EX 10).

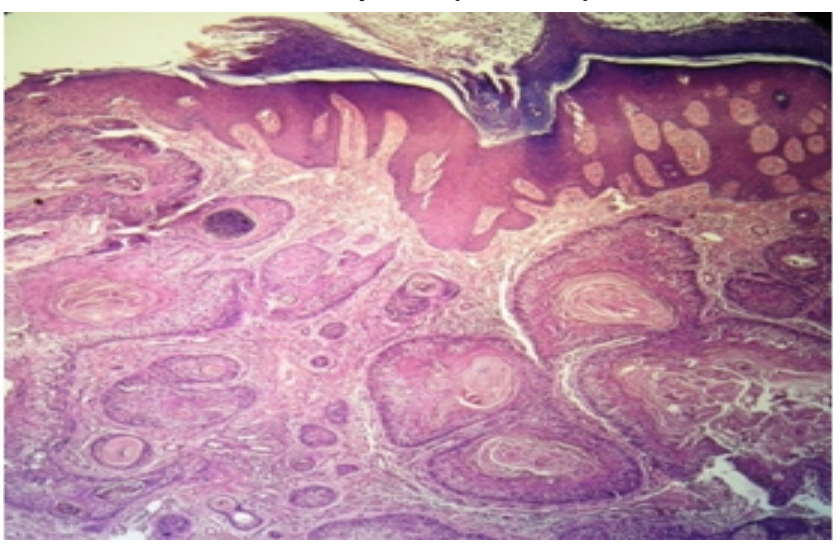

Malignant melanoma is the second most common malignant tumor of skin in this study and the histopathological findings revealed clark level IV in all the cases as shown in table 4 and photomicrograph is shown in Figure 3a, 3b.

Table 4: Histopathological findings in the cases of Malignant Melanoma

\begin{tabular}{|c|c|c|c|c|}
\hline Case & Epidermis & Malignant cell & Dermis & $\begin{array}{l}\text { Clark } \\
\text { level }\end{array}$ \\
\hline $1^{\text {st }}$ Case & $\begin{array}{l}\text { Normal in } \\
\text { thickness }\end{array}$ & $\begin{array}{l}\text { Largely spindle } \\
\text { shaped cell with } \\
\text { melanin pigment }\end{array}$ & $\begin{array}{l}\text { Desmoplastic } \\
\text { reaction noted }\end{array}$ & IV \\
\hline $2^{\text {nd }}$ Case & Atrophic & $\begin{array}{l}\text { Irregular clusters, } \\
\text { nestoid pattern } \\
\text { melanin pigment in } \\
\text { cytoplasm } \\
\text { Some spindle } \\
\text { shaped cells }\end{array}$ & $\begin{array}{l}\text { Lymphocytes and } \\
\text { plasma cell present }\end{array}$ & IV \\
\hline $3^{\text {rd }}$ Case & $\begin{array}{l}\text { Atrophic with } \\
\text { marked ulceration }\end{array}$ & $\begin{array}{l}\text { Lots of melanin } \\
\text { pigment in } \\
\text { epithelial cell and } \\
\text { in histiocytes } \\
\text { Spindle cell pattern }\end{array}$ & $\begin{array}{l}\text { Area of myxoid } \\
\text { change } \\
\text { Intense } \\
\text { lymphoplasmacytic } \\
\text { infiltrate }\end{array}$ & IV \\
\hline $4^{\text {th }}$ Case & $\begin{array}{l}\text { Hyperkeratosis, } \\
\text { parakeratosis } \\
\text { Focal acanthosis } \\
\text { With surface } \\
\text { ulceration }\end{array}$ & $\begin{array}{l}\text { Round to oval } \\
\text { Basophilic to clear } \\
\text { cytoplasm } \\
\text { Some with blackish } \\
\text { brown pigment }\end{array}$ & $\begin{array}{l}\text { Focal necrosis } \\
\text { Foci of marked } \\
\text { desmoplasia }\end{array}$ & IV \\
\hline
\end{tabular}

Figure 3a: Melanoma, hyperkeratosis, epidermal atrophy and atypical spindle shaped cells with melanin pigment occupying whole of the dermis, (H\&E×10).

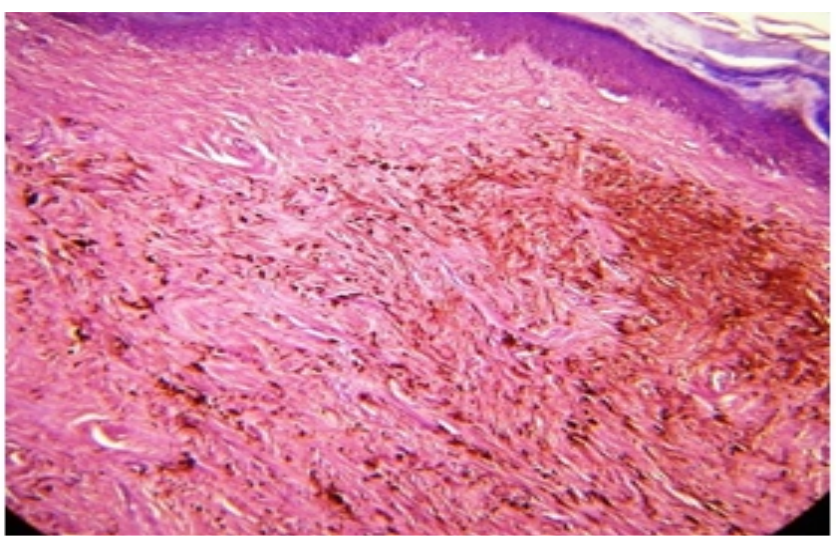


Figure 3b: Bizarre, spindle shaped melanin containing malignant cells, (H \& E × 40)

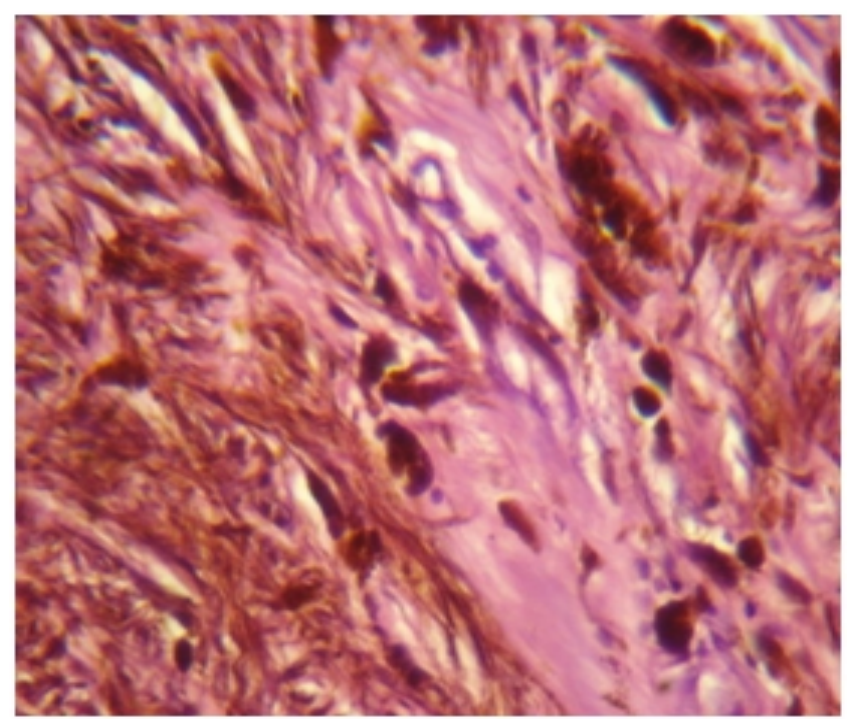

Histomorphological findings of BCC and Adenoid basal cell carcinoma is shown in Figure 4 and Figure 5 respectively.

Figure 4: Basal cell carcinoma, nests of basaloid cells in the dermis with hyperchromatic nuclei and peripheral palisading. Artifactual clefting around tumor nests, ( H\&E×10)

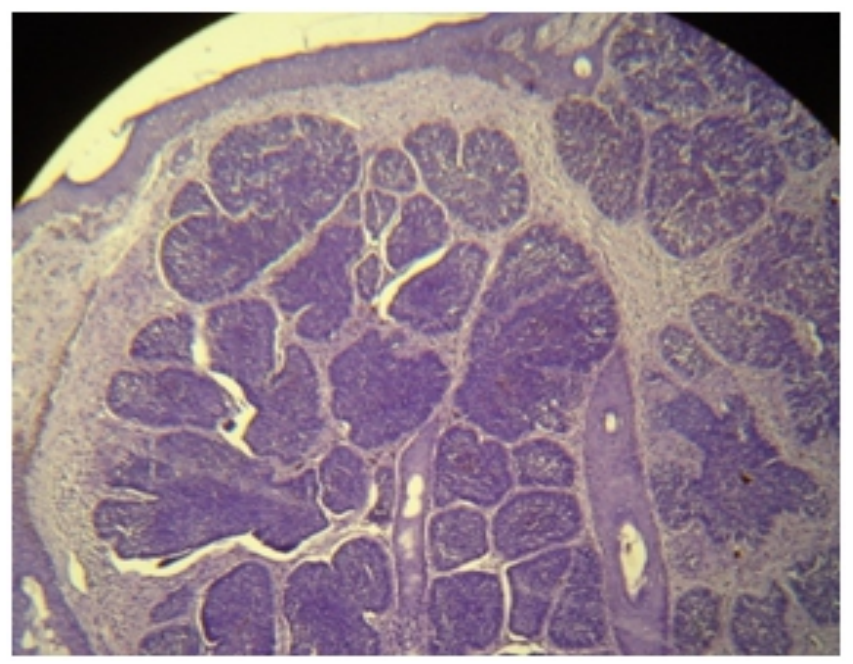

Figure 5: Adenoid Basal cell carcinoma basaloid cells in a reticulate pattern with stromal mucin (H\&E X 10)

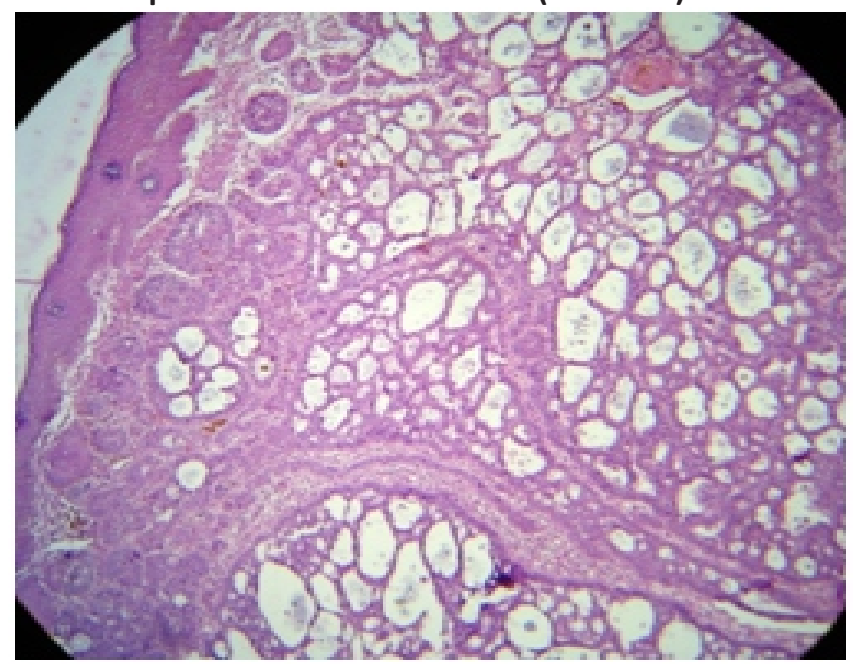

Photomicrograph of mucinous eccrine carcinoma is shown in Figure 6a, 6b.

Figure 6a: Mucinous Eccrine carcinoma, pale mucin surrounding nests of moderately anaplastic epithelial cells, (H\&E×40)

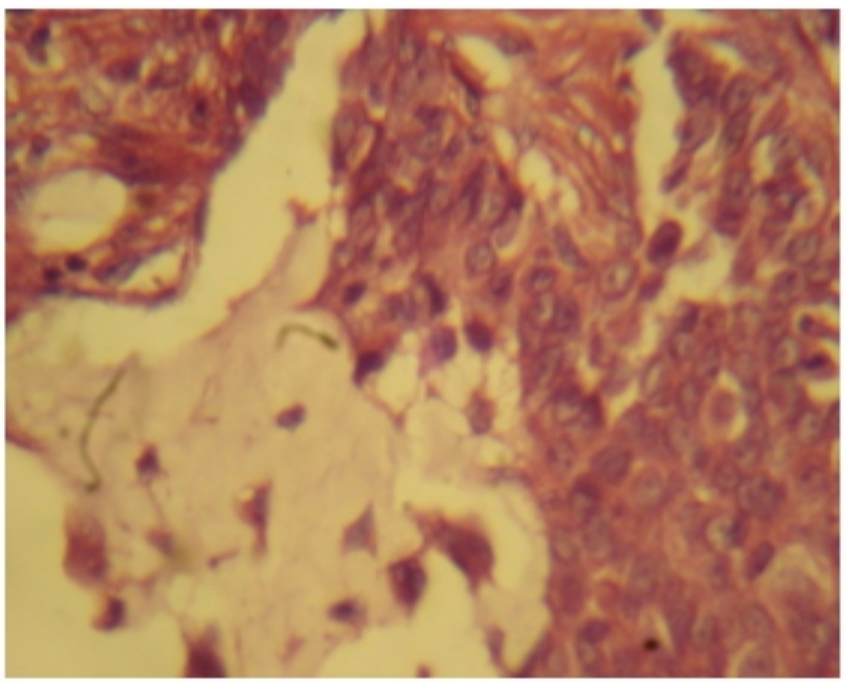

Figure $6 \mathrm{~b}$ : PAS stain of the same case which shows lake of extracellular mucin (arrow), (PAS $\times 10)$.

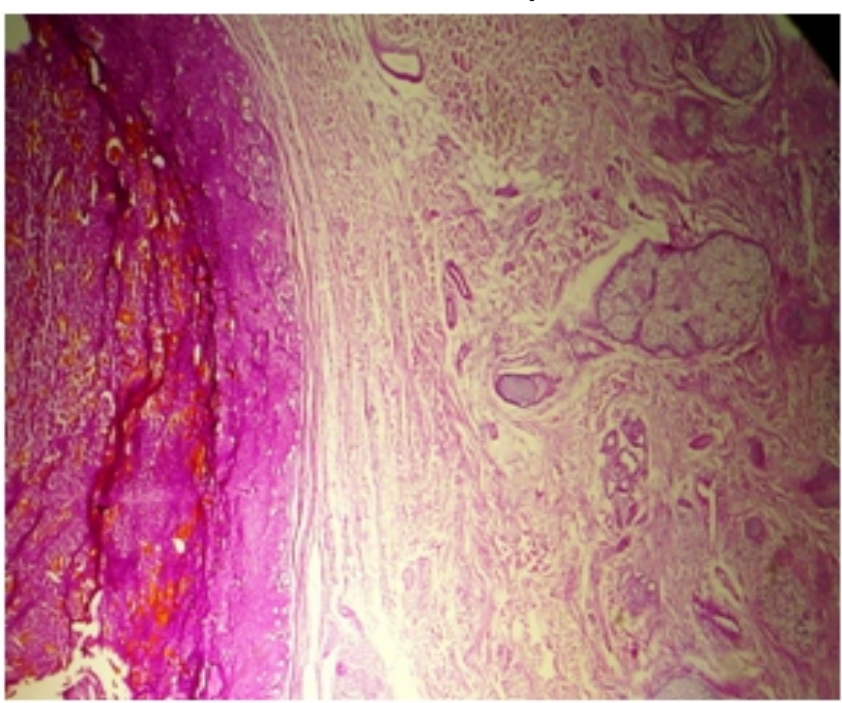

Gross picture and photomicrograph of dermatofibrosarcoma protuberance is shown in Figure 7 a, 7b.

Figure 7a: Dermatofibroscarcoma protuberans Gross: ulceronodular growth (arrow) involving the skin and the subcutis

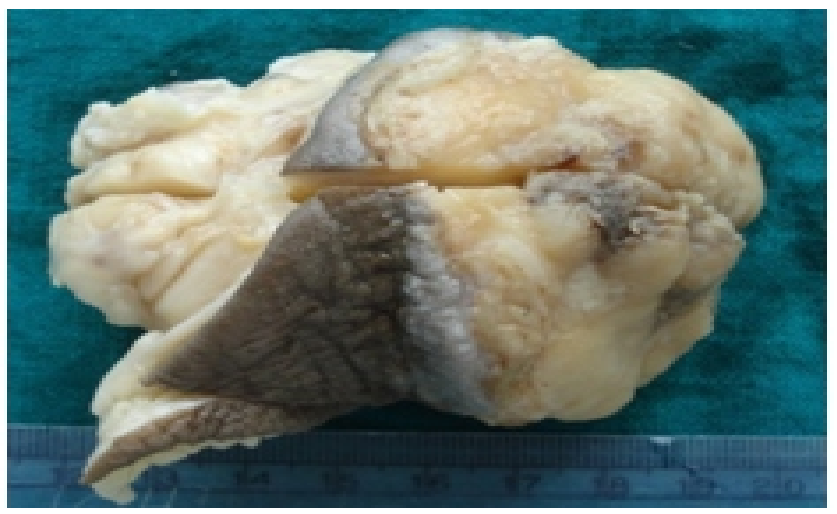


Figure 7b: Photomicrograph Dermatofibroscarcoma protuberans, densely packed, monomorphous, plump spindle cells arranged in a storiform pattern, (H\&E×40)

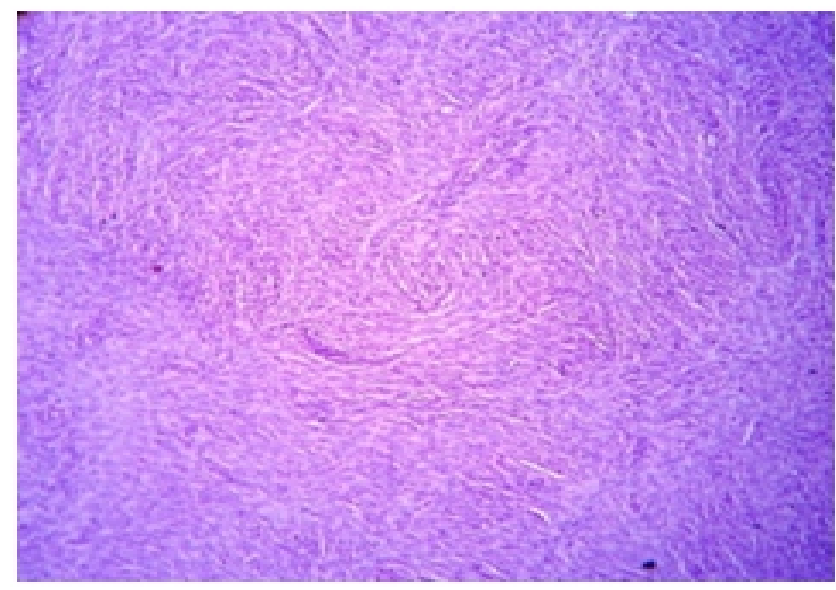

Seven cases diagnosed as benign lesions clinically turned out to be malignant on histopathological examination. Out of 13 cases in which clinical diagnosis was of malignancy, only 8 turned out to be malignant. Thus for malignant lesions, the clinical diagnosis had a sensitivity of $53.3 \%$, specificity of $90.9 \%$ and a positive predictive value of $61.5 \%$. Cross tabulation of these cases is shown in table 5 .

Table 5: Cross tabulation of Histopathological and Clinical diagnoses

\begin{tabular}{|l|r|c|c|}
\hline & \multicolumn{3}{|c|}{ Histopathological diagnosis } \\
\cline { 2 - 4 } & Types of lesion & Malignant & Benign \\
\hline Clinical Diagnosis & Malignant & 8 & 5 \\
\hline & Benign & 7 & 50 \\
\hline & TOTAL & $\mathbf{1 5}$ & $\mathbf{5 5}$ \\
\hline
\end{tabular}

\section{DISCUSSION}

Skin is the largest organ of the human body making $15 \%$ of the total body weight and dermatological manifestations are of varied nature. Very few studies have described and correlated the clinical diagnosis and histopathological results in skin diseases in Nepal. The current study describes the pattern of skin diseases referred for histopathological examination at Nepalgunj Medical College Teaching Hospital, Kohalpur, Nepalgunj. Out of the 1440 different kinds of surgical specimens submitted during the study period of one year from February 2010 to January 2011, only 70 cases were of skin biopsies contributing $4.86 \%$ of total surgical pathology load of the histopathology department. In a similar study performed in a pediatric population, skin biopsies constituted $7.29 \%$ of the total surgical load in a general tertiary care hospital. ${ }^{3}$

In 15 malignant lesions, from our study ( 5 were males and 10 females) and SCC was more in number than BCC. Several studies reveal a preponderance of SCC in Africa whereas in North America and Europe, $80 \%$ of invasive skin cancers are BCC while $20 \%$ are SCC. This reversal of SCC/BCC incidence in Africa could well be due to chronic inflammatory diseases, malnutrition and possibly parasitic infestations. ${ }^{4}$

In our study, head and neck regions were the most common site of malignant tumor and similar findings were noted in other study and also predicted the sun exposure could be the major etiological factor. ${ }^{4-6}$ One of our case of SCC was in a scar tissue in the right knee, patient had history of road traffic accident 12 years back (Figure $2 a$ and $2 b$ ). One case of SCC was present on the left forearm as ulcerated lesion in patient of albinism. These finding were similar to a study reported from Nigeria.

Incidence of SCC were $20 \%$ more common than BCC in black patient according to the information gathered from Tumor registry of Charity Hospital of Louisiana in New Orleans. The most common sites of involvement were face, lower extremities, non-sun exposed areas, and the most common predisposing conditions were scarring processes. ${ }^{8}$ The incidence of skin tumors varies geographically and is relatively well documented for melanoma and to a lesser extent for SCC and BCC in different international samples of the general population. ${ }^{9-11}$

All the four cases of melanoma were present in female in our series and similar sex predilection was noted in other studies. ${ }^{12}$ Three cases presented as nodular swelling and was black in color while other one case was ulcerated type. Lesion was present in foot in two cases and one case each in neck and eyelid margin. Primary melanomas of the eyelid have a nodular pattern and account for less than $1 \%$ of all eyelid malignancies. ${ }^{13}$

Salient morphological features of these four cases are tabulated (Table 4) and microscopic morphology shown in Figure $3 a$ \& $3 b$.

In all the three cases of basal cell carcinoma, lesions were ulcerated, and present on the nose, lateral canthus and post auricular area and in all of them excisional biopsy was done. Two cases were solid type of basal cell carcinoma, with nodular masses of basaloid cells extending into the dermis in relation to a delicate specialized tumor stroma (Figure 4). One of the case was adenoid basal cell carcinoma which is a rare variant of BCC. Microscopically, it showed keratinized stratified squamous epithelium with follicular plugging and dermis showing basaloid tumor cells in lobular and glandular patterns with an edematous loose fibromucinous stroma. Cribriform areas, mucin filled glandular structures and pigment laden macrophages were also seen in the stroma (Figure 5).

Ten cases of skin tumor were arising from adnexal structures comprising $14.2 \%$ in which one case was of malignant mucinous eccrine carcinoma and rest were benign tumor. Similar finding was noted by Paudyal Pet al, in which benign appendageal tumor were more common than malignant appendageal tumor. ${ }^{14}$

In this study the eccrine carcinoma was present in 60 years old male patient, on right cheek and was clinically diagnosed as pyogenic granuloma. Microscopically, epidermal ulceration was continuous with a growth occupying the dermis and getting into the subcutis. This growth showed solid as well as 
a reticulate pattern with mucus lakes in which atypical epithelial cells with moderately acidophilic, finely granular cytoplasm and nucleus with prominent nucleoli were trapped (Figure 6 $a$ and $b$ ). A chronic inflammatory response with foreign body giant cells was also seen in the margins to extravasated mucinous material. However, eccrine carcinoma has been reported most frequently in lower extremity (44\%), trunk $(24 \%)$ and head $(18 \%)$ and only few cases have been reported in the upper extremity ( $8 \%$ ) and hand $(3 \%) .{ }^{15} \mathrm{~A}$ case with dermatofibrosarcoma protuberans in our study was present in 11 year old girl on right ankle and was nodular ulcerated type. These are fibrous histiocytic tumors of intermediate (border line) malignant potential. The tumor is typically centered in the dermis, lacks circumscription, and show high cellularity and storiform pattern of growth (Figure $7 a, b)$. Studies have shown that majority of cases in young adults and presentation during childhood being rare. ${ }^{16}$

In our study, sensitivity of clinical diagnosis of malignancy was $53.3 \%$, specificity $90.9 \%$ and a positive predictive value of $61.5 \%$. Seven cases which were given the clinical diagnosis of benignity turned out to be malignant on histopathological examination. The cases clinically diagnosed as malignant were also proven benign by histopathological examination and the specific diagnosis and categorization of a particular malignancy could not be made clinically. One case of DFSP and melanoma were sent for histopathological examination with the clinical diagnosis of SCC. Histopathological examination thus remains the mainstay for correct diagnosis categorization and for proper management. Sensitivity of clinical diagnosis of malignancy varies widely in the literature with rates ranging from 73 to $91 \%$. Sensitivity for diagnosis

\section{REFERENCES}

1. David E, Rosalie E, Bernett L, George FM. Lever's histopathology of skin. $9^{\text {th }}$ ed.Philadelphia: Lipincott Williams and Wilkins; 2005.

2. LeBoti P., Berg G., Weedon D., Sarasin A. World Health Organization of the Tumours, pathology and genetics of skin tumours. IARC Press, Lyon 2006.

3. Grace Dc, Bendale K, Patil Y. Spectrum of pediatric skin biopsies. Indian Journal of Dermatology. 2007;52(2):111-5.

4. Amir H, Kwesigabo G, Hirji K. Comparative study of superficial cancer in Tanzania. East Afr Med J. 1992 Feb;69(2):88-93.

5. Yakubu A, Mabogunje OA. Skin cancer in Zaria, Nigeria. Trop Doct. 1995;25 Suppl 1:63-7.

6. Ochicha OE, T.; Mohammed, A.Z. \& Umar, A.B. Dermatological Malignancies in Kano, Northern Nigeria: A Histopathological Review. Annals of African Medicine. 2004;3(4):3.

7. Asuquo $M E$, Ikpeme IA, Bassey EE, Ebughe G. Squamous cell carcinoma in South-Eastern equatorial rain forest in calabar, Nigeria. Eplasty. 2009;9:e53.

8. Mora RG, Perniciaro C. Cancer of the skin in blacks. II. A review of thirty-six black patients with squamous cell carcinoma of the lip. J Am Acad Dermatol. 1982 Jun;6(6):1005-9.

9. Christenson LJ, Borrowman TA, Vachon CM, Tollefson MM, Otley CC, Weaver AL, et al. Incidence of basal cell and squamous cell carcinomas in a population younger than 40 years. JAMA. 2005 Aug 10;294(6):681-90. of individual malignancies varies with rates of $95.4 \%$ for BCC, $68 \%$ for SCC, and $67.3 \%$ for MM. Clinicians had a tendency to misclassify benign lesions as malignant, but were less likely to do the reverse. ${ }^{17}$

\section{CONCLUSION}

This study concludes that histopathological examination of the skin lesion is extremely important for categorization of skin tumor. Squamous cell carcinoma is the most common malignant tumor followed by malignant melanoma.

\section{RECOMMENDATION}

This study was conducted in the Mid-Western region of Nepal. It is recommended to conduct such studies throughout the country to have an overall picture and understanding of malignant skin lesions in Nepalese population.

\section{LIMITATION OF THE STUDY}

This is a hospital-based study conducted during the course of one year, and hence, includes the data collected only during that period. The study is based on the cases that were registered in the Hospital, and does not include other probable cases that never reached the Hospital for treatment or diagnosis.

\section{ACKNOWLEDGMENT}

I would like to thank all the faculty from department of Dermatology and department of Surgery of Nepalgunj Medical College and Teaching Hospital.

\section{CONFLICT OF INTEREST}

There are no conflict of interest.

10. Katalinic A, Kunze U, Schafer T. Epidemiology of cutaneous melanoma and non-melanoma skin cancer in Schleswig-Holstein, Germany: incidence, clinical subtypes, tumour stages and localization (epidemiology of skin cancer). Br J Dermatol. 2003 Dec;149(6):1200-6.

11 Brewster DH, Bhatti LA, Inglis JH, Nairn ER, Doherty VR. Recent trends in incidence of nonmelanoma skin cancers in the East of Scotland, 1992-2003. Br J Dermatol. 2007 Jun;156(6):1295-1300.

12 Sharma K, Mohanti BK, Rath GK. Malignant melanoma: a retrospective series from a regional cancer center in India. J Cancer Res Ther. 2009 Jul-Sep;5(3):17380.

13 Rosai J. Rosai and Ackerman's Surgical Pathology. $9^{\text {th }}$ ed. vol 2. Missouri: Mosby; 2004.p.2962-2964.

14 Paudyal P, Agarwal M, A Pradhan, AK Sinha, S Agrawal. A clinicohistopathological study on skin appendageal tumors. Journal of pathology of Nepal. 2016;6:885-891.

15 Scholz IM, Hartschuh W. Primary mucinous eccrine carcinoma of the skin--a rare clinical tumor with many differential diagnoses. J Dtsch Dermatol Ges. 2010 Jun;8(6):446-8.

16 McKee $\mathrm{PH}$, Fletcher CD. Dermatofibrosarcoma protuberans presenting in infancy and childhood. J Cutan Pathol. 1991 Aug;18(4): 241-6.

17 Ek EW, Giorlando F, Su SY, Dieu T. Clinical diagnosis of skin tumours: how good are we? ANZ J Surg. 2005 Jun;75(6):415-20. 